\title{
PERBEDAAN HASIL BELAJAR PEMAHAMAN KONSEP MELALUI PENERAPAN STRATEGI PEMBELAJARAN BERBASIS SELF REGULATED LEARNING
}

\author{
Yowelna Tarumasely \\ IAKN AMBON,Indonesia \\ yowelnatarumasely@gmail.com
}

\begin{abstract}
This study aims to determine whether there is a difference between the learning outcomes of students' understanding of the concept of learning theory before and after applying self-regulated learning-based learning strategies. The research subjects were 46 PAK students in the second semester of the 2019/2020 academic year. Data collection using tests in the form of multiple choices to measure the learning outcomes of learning concept understanding. The method used is quantitative methods, data analysis using a paired sample t-test (paired-sample t-test). The results show that the average posttest score is greater than the pretest average value, this means that there is an increase in student learning outcomes after applying self-regulated learning-based learning strategies, the results also show that the significance obtained is 0.000 , which is less than 0.05 , with thus Ho was rejected and Ha accepted. This means that there is a significant difference between the learning outcomes of students' understanding of the concept of learning theory before and after implementing self-regulated learning-based learning strategies.
\end{abstract}

Keywords: Self-Regulated Learning-based Learning Strategy, Conceptual Understanding.

\begin{abstract}
Abstrak: Penelitian ini bertujuan untuk mengetahui apakah ada perbedaan antara hasil belajar pemahaman konsep Teori Belajar mahasiswa sebelum dan sesudah diterapkan strategi pembelajaran berbasis self regulated learning. Subjek penelitian adalah mahasiswa PAK semester dua tahun ajaran 2019/2020 sebanyak 46 orang. Pengumpulan data dengan menggunakan tes dalam bentuk pilihan ganda untuk mengukur hasil belajar belajar pemahaman konsep. Metode yang digunakan adalah metode kuantitatif, Analisis data menggunakan uji t dua sampel berpasangan (paired sample $t$ Test). Hasil menunjukan nilai rata postest lebih besar dari nilai rata pretest, hal ini berarti ada peningkatan hasil belajar pemahaman konsep mahasiswa sesudah diterapkan strategi pembelajaran berbasis self regulated learning, hasil penelitian juga menunjukan bahwa signifikansi yang diperoleh sebesar 0.000, yang mana lebih kecil dari 0.05, dengan demikian Ho ditolak dan Ha diterima. Hal ini berarti ada perbedaan yang signifikan antara hasil belajar pemahaman konsep teori belajar mahasiswa sebelum dan sesudah diterapkan strategi pembelajaran berbasis self regulated learning.
\end{abstract}

Kata Kunci: Strategi Pembelajaran berbasis Self Regulated Learnng, Pemahaman Konsep. 


\section{PENDAHULUAN}

Kemampuan yang dimiliki oleh seseorang setelah mengikuti proses pembelajaran seringkali disebut sebagai hasil belajar, (Kenedy, Hyland, \& Ryan, 2009). Hasil belajar (Anderson \& Kratwohl, 2010) diklasifikasikan menjadi tiga domain yakni: kognitif, afektif, dan psikomotor. Dalam penerapan ketiga ranah tersebut seseorang harus melaluinya secara bertahap, mulai dari tingkat yang paling sederhana sampai ke tingkat yang paling kompleks. Salah satu bentuk pencapaian atau hasil belajar ranah kognitif adalah pemahaman konsep. Pemahaman konsep merupakan dasar pijak bagi sesorang untuk membangun pengetahuan selanjutnya. Dengan pemahaman konsep yang baik akan memudahkan peserta didik untuk mengembangkan kemampuannya. Hal yang sama juga dikemukan oleh Mills (2016) bahwa pemahaman konsep merupakan suatu dasar untuk mengkonstruk pengetahuan berikutnya.

Penelitian dalam dunia pendidikan yang membahas tentang pemahaman konsep bagi peserta didik telah banyak dilakukan baik itu yang terkait dengan usia, tingkat pendidikan juga yang terkait dengan bidang lain. Hasil yang ditemukan menunjukan bahwa pemahaman konsep yang dimiliki oleh peserta didik tidak lengkap atau tidak akurat dalam bidangnya masing-masing. Pemahaman konsep bukan sekedar kemampuan untuk menghafal berbagai informasi, tetapi lebih dari itu dibutuhkan suatu kemampuan agar informasi yang telah diperoleh dapat diaplikasi pada pengalaman atau situasi yang tak terduga lainnya (Saricayir et. Al., 2016). Dengan pemahaman konsep yang baik siswa mampu untuk menaiki tingkatan kognitif yang lebih komplek, (Fitriyane, et. al., 2018). Sejalan dengan hal itu Sugiarti dalam Jaya F., \& Arnilya L (2019) mengemukakan bahwa upaya untuk membangun pemahaman konsep peserta didik merupakan suatu masalah yang penting dalam dunia pendidikan yang perlu dicari bagaimana cara pemecahannya.

Pentingnya pemahaman konsep sebagai bentuk penguasaan dasar peserta didik terhadap pelajaran yang telah disampaikan oleh pendidik, dirasakan perlu juga bagi mahasiswa khususnya semester kedua. Mengingat bahwa mahsiswa semester kedua dikategorikan sebagai mahasiswa yang masih baru pada dunia perguruan tinggi, dengan demikian membutuhkan proses penyesuaian dengan 
iklim akademis di perguruan tinggi, salah satu diantaranya adalah strategi pembelajaran. Strategi pembelajaran di perguruan tinggi berbeda dengan strategi pembelajaran yang diperoleh di sekolah menengah, yang mana guru lebih dominan daripada siswa, siswa hanya sebagai pendengar, bahwa guru yang lebih berperan dalam mengatur pembelajaran siswa, tentang kapan, di mana, sumber apa yang akan dipakai sampai bagaimana cara siswa itu belajar atau pembelajaran berpusat kepada guru (teacher centered learning).

Menurut Vishnumolakala, et.al., (2017) pada teacher centered learning dinamika pembelajaran yang terjadi cenderung menjadikan siswa sebagai penerima informasi (resptoar pasif) tanpa mempertimbangkan mereka untuk berpartisipasi secara aktif, sehingga membuat mahasiswa kurang memiliki kemandirian dalam belajar, kurangnya motivasi untuk berusaha, kurangnya kemampuan untuk mentransfer pengetahuan yang dimiliki, kurangnya keyakinan diri terhadap kemampuanya sendiri, kurangnya kemampuan untuk meregulasi diri dalam belajar, dan juga menjadikan mereka tidak ideal dalam mengembangkan ketrampilan berpikir. Sementara strategi pembelajaran pada perguruan tinggi mahasiswa dituntut untuk lebih aktif, mahasiswa harus diberikan kesempatan untuk mengatur pembelajaran mereka sendiri tentang kapan, di mana, sumber apa yang akan dipakai sampai bagaimana cara belajar.

Strategi pembelajaran yang sesuai dengan hakekat belajar di perguruan tinggi adalah strategi pembelajaran yang memberikan kesempatan kepada mahasiswa mengatur dirinya sendiri untuk belajar atau self regulated learning. Self-regulated learning merupakan kegiatan di mana individu yang belajar secara aktif, menyusun, menentukan tujuan belajar, merencanakan dan memonitor, mengatur dan mengontrol kognisi, motivasi perilaku serta lingkungannya untuk mencapai tujuan yang telah ditetapkan (Pintrich, 2004; Wolters, et. al., 2003). Beberapa hasil penelitian menunjukan bahwa strategi pembelajaran self regulated learning sangat efektif digunakan sebagai strategi pembelajaran untuk meningkatkan hasil belajar dalam memahami fakta, konsep, prinsip dan prosedur.

Strategi self regulated learning membantu mahasiswa dalam menentukan langkah pertama untuk belajar, menentukan kebutuhan mereka, menetapkan tujuan belajar mereka, mengeksplorasi sumber belajar, mengatur waktu dan lingkungan, 
dan menerapkannya secara efektif untuk mencapai hasil belajar yang memuaskan (Zhu, Au \& Yates, 2016). Veeanam (1999) mengemukan bahwa strategi self regulated learning berpengaruh terhadap penerapan teori pada praktik pengobatan di dalam kelas. Pauli (2007) menyatakan bahwa strategi self regulated learning berpengaruh pada kemampuan siswa pemecahan masalah matematika secara independen.

\section{METODE PENELITIAN}

Penelitian ini menggunakan penelitian ekperimen semu untuk menguji hipotesis mengenai hubungan sebab akibat antar variable (Degeng,2000:13). Desain penelitian yang digunakan adalah pretest-postest control group design (Setyosari, 2012). Subjek penelitian adalah mahasiswa semester dua program studi PAK pada IAKN Ambon tahun akademik 2019/2020, berjumlah 46 orang. Selama proses pembelajaran berlangsung, semua mahasiswa mengikuti dari awal kegiatan pembelajaran sampai akhir, baik pada saat melakukan pretest maupun posttest, dengan demikian subjek penelitiannya berjumlah 46 orang.

Instrument yang digunakan dalam penelitian ini adalah tes. Bentuk Tes adalah pilihan ganda, untuk mengukur pemahaman konsep. Jumlah soal yang dipakai sebanyak 25 butir soal dengan skor nilai untuk jawaban benar 1 dan skor nilai 0 untuk jawaban yang salah. Data yang dianalisis terbagi dua, yang pertama sebagai persyaratan untuk melakukan analisis uji paired sample t test dan yang kedua untuk menguji hipotesis penelitian. Untuk persyaratan analisisnya berupa uji normalitas data. Uji normalitas data menggunakan Kolmogorov-Smirnov. Analisis data untuk menguji hipotesis penelitian menggunakan teknik statistic uji paired sample t test dengan program SPSS 19. for Windows. Dan semua uji asumsi parametric dilakukan pada nilai signifikansi $5 \%$. 


\section{HASIL DAN PEMBAHASAN}

\section{HASIL}

\section{Deskripsi Hasil Pretest Pemahaman Konsep}

Sebelum dilakukan penelitian terlebih dahulu dilakukan pretest kepada mahasiswa yang akan terlibat dalam penelitian untuk mengetahui kemampuan awal yang dimiliki oleh mereka terkait dengan Mata Kuliah Teori Belajar. Hasil pretest hasil belajar pemahaman konsep mahasiswa seperti pada table di bawah ini:

Tabel 1. Data Hasil Pretest Pemahaman Konsep.

\begin{tabular}{lccccc}
\hline & N & Min & Max & Mean & Std.D \\
\hline Pretest & 46 & 60 & 76 & 68,00 & 5.400
\end{tabular}

Tabel 1 menunjukan bahwa nilai rata- rata hasil pretest hasil belajar pemahaman konsep mahaiswa sebesar 68.00, dengan standar deviasi sebesar 5.400, sementara nilai maximal yang diperoleh sebesar 76 dan nilai minimum sebesar 60.

\section{Deskripsi Hasil Posttest Pemahaman Konsep}

Hasil post test pemahaman konsep dalam penelitian ini diperoleh setelah kelompok subyek penelitian mendapat perlakuan dengan strategi pembelajaran berbasis self regulated learning. Hasil posttest pemahaman konsep ditunjukan pada table2 di bawah ini.

Table 2. Data Posttest Hasil Belajar Pemahaman Konsep

\begin{tabular}{lccccc}
\hline & N & Min & Max & Mean & Std.D \\
\hline Pretest & 46 & 60 & 88 & 74.26 & 7.431 \\
\hline
\end{tabular}

\section{Uji Persyaratan Analisis}

Untuk melakukan pengujian terhadap hipotesis yang diajukan dalam penelitian ini, maka variabel - variabel yang diteliti baik itu variabel bebas yakni strategi pembelajaran berbasis self regulated learning dan variabel terikat yakni hasil belajar pemahaman konsep, diuji dengan menggunakan analisis melalui uji t dua sampel berpasangan (paired sample $t$ test). Sebelum melakukan analisis 
terlebih dahulu dilakukan pemeriksaan data hasil penelitian dengan uji persyaratan analisis Paired Sample t Test, yaitu uji normalitas

\section{Uji Normalitas}

Uji normalitas digunakan untuk mengetahui data berdistribusi normal ataukah tidak sebagai salah satu uji prasyarat untuk melakukan uji analisis Paired Sample t Test. Berikut hasil uji normalitas data posttest pemahaman konsep:

Tabel 3. Hasil Uji Normalitas Data Pretest dan Posttest Hasil Belajar Pemahaman Konsep

\section{Tests of Normality}

\begin{tabular}{lr|r|r|r|r|r} 
& \multicolumn{3}{c|}{ Kolmogorov-Smirnov $^{\text {a }}$} & \multicolumn{4}{c}{ Shapiro-Wilk } \\
& Statistic & df & \multicolumn{1}{c|}{ Sig. } & Statistic & df & \multicolumn{1}{c}{ Sig. } \\
\hline Pretest & .140 & 46 & .024 & .903 & 46 & .006 \\
\hline posttest & .120 & 46 & .097 & .962 & 46 & .131 \\
\hline
\end{tabular}

a. Lilliefors Significance Correction

Berdasarkan table di atas hasil uji normalitas menggunakan KolmogorovSmirnov menunjukan bahwa nilai signifikansi hasil belajar pemahaman konsep untuk pretest sebesar 0.24 , hal ini berarti hasil pretest berdistribusi normal dan hasil posttest sebesar 0.97, dengan demikian nilai signifikansi pretest dan postest lebih besar dari $0.05(0,24>0,05,0,97>0,05)$. Hal ini berarti data hasil belajar pemahaman konsep berdistribusi normal.

\section{Pengujian Hipotesis Penelitian}

Hipotesis dalam penelitian ini adalah:

H0: tidak ada perbedaan yang signifikan antara hasil belajar pemahaan konsep teori belajar sebelum dan sesudah menggunakan strategi pembelajaran berbasis self regulated learning

Ha: ada perbedaan yang signifikan antara hasil belajar pemahaan konsep teori belajar mahasiswa sebelum dan sesudah menggunakan strategi pembelajaran berbasis self regulated learning 
Untuk menguji hipotesis di atas berikut dipaparkan hasil analisis uji paired sample t test berupa paired sample statistic, paired sample corelation dan paired sample test (sig-2tailed) pada table di bawah ini:

\section{Tabel 4. Paired Samples Statistics}

\begin{tabular}{llr|r|r|r} 
& & Mean & N & Std. Deviation & Std. Error Mean \\
\hline Pair 1 & Pretest & 68.00 & 46 & 5.400 & .796 \\
\cline { 2 - 6 } & posttest & 74.26 & 46 & 7.431 & 1.096 \\
\hline
\end{tabular}

Hasil uji t di atas menunjukan bahwa nilai rata - rata pretes adalah 68.00 dan rata -rata nilai postest adalah 74.00 , demikian nilai rata-rata sesudah menerapkan strategi pembelajaran self regualted learning lebih besar dibandingkan sebelum. Hal ini berarti ada peningkatan hasil belaajr pemahaman konsep sesudah penerapan strategi pembelajaran Self Regulated learning.

Tabel 5. Paired Samples Statistics

\begin{tabular}{rrr|r|r} 
& N & Correlation & \multicolumn{1}{c}{ Sig. } \\
\hline Pair 1 & Pretest \& posttest & 46 & .868 & .000 \\
\hline
\end{tabular}

Hasil uji paired sample corelations menunjukan bahwa nilai signifikansi sebesar 0.000 , di mana nilai sig > dari 0.00 , hal ini berarti antara pretest fan posttest memiliki hubungan atau ada hubungan yang siginifikan

Tabel 5 Paired Samples Correlations

Paired Samples Test

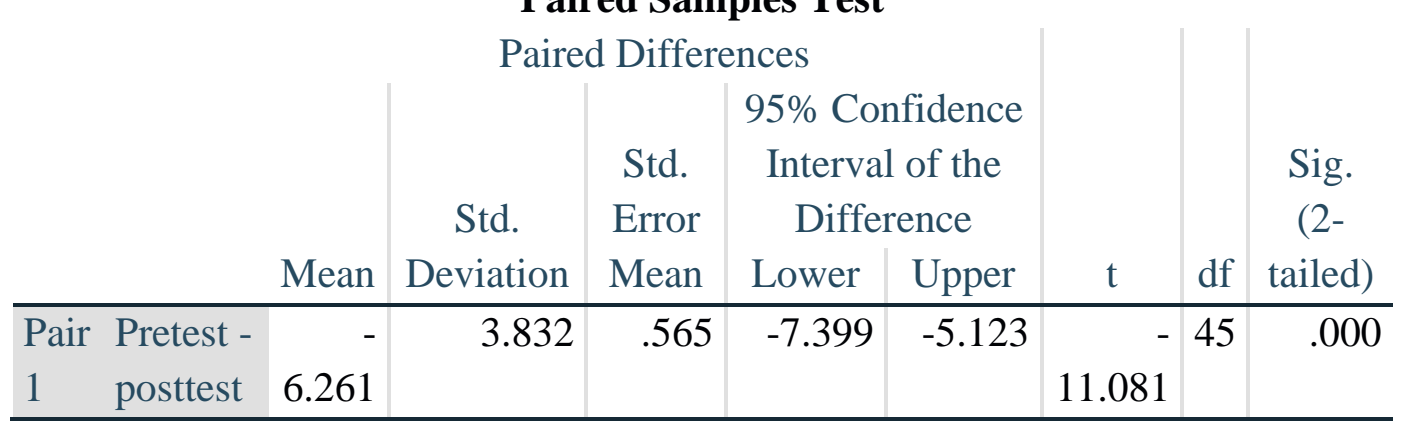


Hasil uji t berupa Paired sample Test menunjukan bahwa nilai signifikaansi sebesar 0.000, berarti kurang dari 0.05, maka Ho ditolak. Hal ini berarti bahwa hasil belajar sebelum dan sesudah menggunakan strategi pembelajaran self regulated learning. tidak sama. Dengan demikian dapat dikatakan bahwa terdapat perbedaan yang signifikan antara hasil belajar pemahaman konsep Teori Belajar mahasiswa sebelum dan sesudah penggunaan strategi self regulated learning..

\section{PEMBAHASAN}

Berdasarkan hasil uji hipotesis, maka hipotesis pertama dalam penelitian ini yaitu: ada peningkatan hasil belajar pemahaman konsep mahasiswa sesudah menggunakan strategi self regulated learning., dibandingkan sebelum menggunakan yang strategi pembelajaran berbasis self regulated learning. Hasil penelitian ini mendukung hasil penelitian Najabati (2015) strategi self regulated learning mempengaruhi pemahaman membaca, sebagimana yang diungkapkan oleh Zhu,Au \& Yates ( 2016), membantu mahasiswa menentukan langkah-langkah untuk belajar dan dapat meningkatkan hasil belajar apabila langkah- langkah tersebut diterapkan secara efektif.

Nurlaela (2012), melakukan penelitian untuk melihat pengaruh strategi self regulated learning., motivasi berprestasi dan locus of control terhadap hasil belajar maintenance repair pebelajar SMA, hasil penelitian menunjukkan bahwa ada perbedaan hasil belajar antara pembelajar yang belajar dengan strategi self regulated learning. dan kelompok pebelajar dengan strategi teacher regulated learning. Hal ini berarti strategi self regulated learning. lebih unggul dalam meningkatkan hasil belajar maintenance repair daripada strategi TRL. Lebih lanjut dikatakan bahwa strategi SRL merupakan salah satu alternatif strategi belajar yang tepat untuk materi yang berkaitan dengan kemampuan pemahaman dan penerapan konsep pada dimensi pengetahuan prosedur, sebagai aktivitas kognitif.

Siti Suminarti dan Siti Fatimah (2013), melakukan penelitian untuk melihat pengaruh self regulated learning. terhadap peningkatan IP mahasiswa. Hasil penelitian menunjukkan bahwa, kelompok mahasiswa yang menerapkan self regulated learning. memiliki prestasi akademik lebih tinggi dibandingkan dengan mahasiswa yang tidak menggunakan self regulated learning. 
Najabati (2015) melakukan penelitian berkaitan dengan dampak strategi pembelajaran SRL terhadap kemapuan membaca pemahaman. Hasil penelitian menunjukkan bahwa mengajar dengan strategi SRL, memberikan pengaruh terhadap kemampuan pemahaman membaca, lebih lanjut dikatakan bahwa temuan ini dapat membantu pengajar untuk meningkatkan hasil belajar pemahaman membaca secara khusus dan hasil belajar lainnya secara umum. Selain itu disarankan juga untuk para guru dan desainer silabus atau kurikulum agar dapat menggunakan strategi self regulated learning. untuk merancang kurikulum dan dalam proses pembelajaran.

Penelitian ini menemukan bahwa dalam penerapan strategi pembelajaran berbasis self regulated learning., pebelajar menggunakan kemampuan metakognisi sehingga membantu mereka menyusun tahapan tahapan untuk belajar. Tahapan tahapan tersebut antara lain: tahap pertama adalah forethought, planning and activation atau tahap perencanaan, di mana pebelajar menentukan tujuan yang hendak mereka capai. Pada tahap ini berdasarkan tujuan pembelajaran yang telah disampaikan oleh pembelajar, pebelajar menganalisis dan mengidentifikasikan tujuan-tujuan tersebut sesuai dengan kemampuan yang mereka miliki. Mereka menetapkan target yang akan mereka capai berdasarkan tujuan yang diberikan, mencermati dan menentukan sumber belajar dan memilih tempat yang nyaman untuk mereka belajar. Bagi pebelajar yang memilih buku sebagai sumber belajar maka mereka akan memilih perpustakaan sebagai tempat belajar, dan jika mereka memilih sumber belajar yang lain misalkan internet maka mereka akan belajar di tempat di mana mereka terkoneksi dengan jaringan internet bahkan ada yang belajar di luar ruangan. Terkait dengan tahap perencanaan hal ini sejalan dengan apa yang dikemukakan oleh (Pintrich 2004) yang mengatakan bahwa self regulated learning. merupakan proses agresif yang digunakan oleh pebelajar untuk meningkatkan ketrampilan akademik dan tujuan belajarnya.

Tahap kedua adalah monitoring (controlling), pada tahap monitoring pebelajar melakukan monitoring atau pengawasan untuk mengukur kemampuan yang telah mereka capai. Pengawasan ini dilakukan berdasarkan alokasi waktu yang ditetapkan secara umum oleh pembelajar maupun waktu yang mereka tentukan pada tahap perencanaan, sehingga mereka dapat mengetahui kemajuan belajar yang telah dicapai juga kendala kendala yang mereka hadapi. Kegiatan ini sejalan dengan apa yang 
dikemukan oleh Cheng (2011), bahwa strategi pembelajaran berbasis SRL mengharuskan pebelajar untuk memantau proses pembelajrannya sendiri, apabila menemui kesulitan atau memerlukan bantuan orang lain, dapat meminta bantuan kepada pembelajar ataupun juga kepada teman sebaya, kegiatan monitoring juga termasuk memprediksi hasil belajarnya sendiri.

Tahap ketiga adalah Reaction and reflection atau tahap evaluasi, pada tahap ini pembelajar melakukan evaluasi terhadap pencapaian tujuan sesuai yang telah mereka tetapkan, selanjutnya pebelajar membuat refleksi terhadap proses dan hasil yang telah dicapai, dan menetapkan perencanaan baru, menetapkan tujuan yang baru untuk proses berikutnya. Hal ini sejalan dengan Zumbrun, et al (2011) yang mengemukakan bahwa pada strategi self regulated learning., kegiatan mengevaluasi kinerja, menilai kemajuan belajar dan menilai hasil belajar dilakukan secara mandiri. Pintrich (2004) mengatakan bahwa perilaku perilaku mulai dari perencanaan sampai kepada mengevaluasi, merupakan bagian dari strategi SRL, yang dapat menolong pebelajar untuk merencanakan belajarnya dan mengevaluasi, sehingga dapat meningkatkan prestasi belajar. Dimensi perilaku seperti ini mencerminkan kebiasaan kegiatan yang dilakukan oleh pebelajar untuk mengolah dan mengatur pembelajaran mereka ( Lee dan Shute, 2010).

\section{SIMPULAN}

Berdasarkan hasil penelitian dan pembahasan di atas menunjukan bahwa strategi pembelajaran berbasis self regulated learning memberikan pengaruh secara signifikan terhadap hasil belajar pemahaman konsep Teori belajar mahasiswa. Dengan demikian dapat disimpulkan bahwa ada perbedaan signifikan antara hasil belajar pemahaman konsep sesudah menggunakan strategi pembelajaran berbasis self regulated learning. Selain itu, hasil penelitian juga menunjukan bahwa strategi pembelajaran berbasis self regulated learning dapat meningkatkan hasil belajar. 


\section{DAFTAR RUJUKAN}

Anderson, L.W., \& Kratwohl, D.R., Airasian, P.W., Cruikshank,KA., Mayer P.E, Pintrich, Raths, J., M Wittrock,M.C., 2010, A Taxonomy for Leaarning Teaching and Assesing: A Revision of Bloom Taxonomy of Educational Objectives, (Eds) Abridges Edition: New York: Longman

Cheng, E.C. (2011). The role of self-regulated learning in enhancing learning performance. The International Journal of Research and Review, 6 (1),

Degeng, I.N.S. 1989. Ilmu Pengajaran Taksonomi Variabel. Jakarta: Depdikbud, Ditjendikti, P2LPTK.

Fitriyane Laila Apriliani Rahmat, Suwatno, Rasto improving students' conceptual understanding through teams games tournament (tgt): meta, manajerial, $\begin{array}{llllll}\text { vol. } & 3 & \text { no.5 juni 2018, } & & \end{array}$ http://ejournal.upi.edu/index.php/manajerial/analysis

JayaF., \& ArnilyaL. (2019). Pengaruh Penggunaan Media Pembelajaran AudioVisual dengan Microsoft Powerpoint Terhadap Keaktifan dan Pemahaman Belajar Siswa Kelas x pada Mata Pelajaran Sosiologi di MA NU Islamiyah Asembagus. Edusaintek : Jurnal Pendidikan, Sains dan Teknologi, 6(2)

Kennedy, D., Hyland, Á., \& Ryan, N. (2009). Learning Outcomes and Competences, 1(18), c

Lee dan Shute,2010 Personal and Social-Contextual Factors in K-12 Academic Performance: An Integrative Perspective on Student Learning Mills,(2016), Possible Effects of Internet Use on Cognitive Development in Adolescence https://www.cogitatiopress.com/mediaandcommunication/article/view/51 $\underline{6}$

Najva Najabati (2015) The Effects of Teaching Self-regulated Learning Strategies on EFL Students' Reading Comprehension. http://www.academypublication.com/ojs/index.php/jltr/article

Nurlaela, (2012) Pengaruh Strategi Self Regulated Learning, Motivasi Berprestasi dan Locus Of Control Terhadap Hasil Belajar Maintance Repair Mahasiswa SMK. 
Pauli, K. Reusser, and U. Grob, "Teaching for understanding and/or self-regulated learning? A video-based analysis of reform-oriented mathematics instruction in Switzerland," International Journal of Educational Research, vol. 46, no. 5, pp. 294-305, 2007.

Pintrich, P.R. 2004. The Role of goal orientation in self-regulated learning. In M. Bokaerts, P. Pintrich, \& M. Zeidner (Eds) Handbook of self-regulation. San Diego, CA: Academic Press, pp. 452-502.

Setyosari,2013. Metode Penelitian Pendidikan dan Pengembangan, PT Kharisma Putra Utama. Jakarta.

Saricayir, H., Ay, S., Comek, A., Cansiz, G., \& Uce, M. (2016). Determining Students ' Conceptual Understanding Level of Thermodynamics. Journal of Education and Training Studies, 4(6), 69-79. https://doi.org/10.11114/jets.v4i6.1421

Siti Suminarti \& Siti Fatimah,2013, Self-Regulated Learning (Srl) Dalam Meningkatkan Prestasi Akademik Pada Mahasiswa, Jurnal Ilmiah Psikologi Terapan ISSN: 2301-8267 Vol. 01, No.01, Januari 2013.

Sugiarti, A. A. S. (2012). Pengaruh Penerapan Model Pembelajaran Kooperatif GI terhadap Pemahaman Konsep Kimia dan Kemampuan Berpikir Kreatif Siswa SMAN 3 Denpasar. Jurnal Penelitian Pascasarjana Undiksha, 2(1), S. Veenman, D. Beems, S. Gerrits, and G. Op de Weegh, "Implementation effects of a training program for self-regulated learning," Journal of Research \& Development in Education, vol. 32, no. 3, pp. 148-159, 1999. View at Google Scholar

Vishnumolakala, et,al (2017). Students' Attitudes, Self-Efficacy And Experiences In A Modified Process-Oriented Guided Inquiry Learning Undergraduate Chemistry Classroom,

Zhu, Y.,Anu, W., Yates, G. 2016. University student's self control and self regulated learning in a blended course. Journal internet and highereducation,

Zumbrunn, et al 2011, Encouraging Self-Regulated Learning in the Classroom : A Review of the Literature, Virginia Commonwealth University. 